\title{
Conversation and Community Building in Jane Austen’s Novels
}

\author{
WANG Wan-ying \\ Hangzhou Normal University, Hangzhou, China
}

\begin{abstract}
In recent years, much attention from home and abroad has been paid to the role that conversation plays in building community in Jane Austen’s novels. But the interpretations are merely confined to one or two of Austen's novels. Actually, her six novels all have embodied her devotions to conversation and community building. Through literary language, she has fully demonstrated us how to shape community through proper conversation. Only the conversation that unites both sincerity and politeness is bound to help form peaceful and warm community.
\end{abstract}

Keywords: Jane Austen, conversation, community building

Jane Austen (1775-1817) has been regarded as "the doyenne of conversation" in the history of British literature. In recent years, much attention from home and abroad has been paid to the role that conversation plays in shaping community in Austen's novels . In Conversable Worlds: Literature, Contention and Community 1762 to 1830 (2011), British Professor Jon Mee devotes one chapter to explore Jane Austen’s “conversable world” (Mee, 2011, p. 201). Mainly discussing one of Austen's novel Emma (1815), he concludes that conversation in Austen's novels "meets a form of sceptical resistance that complicates any inclusive build-up of community” (Mee, 2011, p. 234). However, Chinese critic Yin Qiping points out that Jon Mee overlooks Austen’s contributions to community building by displaying proper conversation (Yin, 2016, p. 49). He elaborates on some conversations from Pride and Prejudice (1813), in which "the spirit of community finds expression in a strong sense of propriety" (Yin, 2016, p. 40). But interpreting only one or two novels is not convincing enough and it is necessary to ponder on this question in terms of all of Austen's novels. In fact, in the six novels she has created throughout her life, conversation is bound up with her imagination of community shaping. Based on close reading of her six novels, this thesis intends to illustrate how Austen uses conversation to fulfill her wish of building community.

To discuss Austen's conversable world, it is necessary not to avoid the literary traditions she inherits or she has been influenced. In British history, there is a heated debate between "the polite model of conversation" and "the combative model of conversation" (Yin, 2016, p. 47). The former is mainly represented by Richard Steel (1672-1729), Joseph Addison (1672-1719) and David Hume (1711-1776), promoting to "suppress difference and bring the play of particularities into balance” (Mee, 2011, p. 42). In other words, it emphasizes the values of politeness, balance and peace for conversation, thus it is called "the polite paradigm" or "the Humean paradigm" (Yin, 2016, p. 48). On the other hand, the combative model of conversation attaches more importance to "the vigorous pursuit of knowledge” through conversation (Mee, 2011, p. 16). Its representatives, such as Issac Watts (1674-1748), Samuel Johnson (1709-1784) and William Godwin (1756-1836), overlook the importance of

WANG Wan-ying, MA candidate, Hangzhou Normal University, mainly engaged in the studies of British and American literatures. Her e-mail is wwy0208@qq.com. 
politeness and pursue "mutual collisions of ideas" through conversing together (Mee, 2011, p. 16). According to John Mee, neither the politeness paradigm nor the rational-critical account of eighteenth-century conversation properly accounts for this congested and contested terrain, although both describe tendencies that contemporaries recognized and fought over within it (Mee, 2011, p. 16). He argues that Austen "inherits at least one tradition of the novel that is committed to the Humean idea of the conversable world" and is at least influenced by Hume, Richardson and others (Mee, 2011, p. 207). Pro.Yin holds that the ideal conversation must be a unity of both civility and truth, which is exactly what Austen promotes in her novels (Yin, 2016, p. 49). Unfortunately, he only elaborates on only one novel Pride and Prejudice. Actually, among her six novels, it is not difficult to find her inheritance as well as criticism of both the polite paradigm and the combative paradigm, or in other words, her requirement of both sincerity and politeness for proper conversation.

\section{Austen's Main Principles of Conversation}

\subsection{Sincerity}

Both John Mee and Pro. Yin have commented on a conversation in Emma, which may illustrate Austen's views of the polite paradigm. Here Emma admires Churchill's ability of conversation while Knightley criticizes his lack of sincerity:

"My idea of him is, that he can adapt his conversation to the taste of every body, and has the power as well as the wish of being universally agreeable. To you, he will talk of farming; to me, of drawing or music; and so on to every body, having that general information on all subjects which will enable him to follow the lead, or take the lead, just as propriety may require, and to speak extremely well on each.”

“And mine,” said Mr. Knightley warmly, “is, that if he turn out anything like it, he will be the most insufferable fellow breathing......” (Austen, 2008, p. 118)

What Mr. Knightley points out is that "such protean politeness would sacrifice too much sincerity” (Mee, 2016, p. 205). Pro. Yin attaches more importance to the word "propriety”, implying that Churchill's conversation is a specimen of impropriety. However, in Austen's novels, there is always a male figure "being universally agreeable” at first but disappointing people at last, such as Mr. Churchill in Emma, Mr. Wickham in Pride and Prejudice and Mr. Elliot in Persuasion (1818) (Austen, 2008, p. 118). For instance, in Pride and Prejudice, Elizabeth is firstly captivated by Mr. Wickham, especially by his conversation: "Whatever he said was said well; and whatever he did, done gracefully” (Austen, 2003, p. 73). But knowing him better, she begins to realize how improper his conversation is.

She perfectly remembered everything that had passed in conversation between Wickham and herself in their first evening at Mr. Philips... She was now struck with the impropriety of such communications to a stranger, and wondered it had escaped her before. She saw the indelicacy of putting himself forward as he had done, and the inconsistency of his professions with his conduct. (Austen, 2003, p. 177)

From above words, especially "impropriety" and "indelicacy”, it implies that how Austen emphasizes the value of propriety for conversation. Besides, it also indicates that the impropriety of Wickham's conversation lies in its lack of truth. His words, though of all politeness, are proved to be contradictory to the fact or inconsistent with his behaviors. Thus sincerity is one of the basic elements of Austen's ideal conversation, in other words, proper conversation requires a unity of both sincerity and civility. 
In Austen's last novel Persuation, Mr. Elliot is also criticized for his lack of candour. Mr. Elliot is a person who "talked well, professed good opinions, seemed to judge properly", but Anne still points out his want of openness, which is "a decided imperfection” (Austen, 2013, p. 146). Moreover, what Anne prizes "beyond all others" is "the frank, the open-hearted, the eager character" (Austen, 2013, p. 146). In this way, lack of sincerity is "a decided imperfection", a distinct disadvantage for frankness, openness or sincerity is regarded as the most valuable quality (Austen, 2013, p. 146). Thus it reveals Austen's emphasis on openness as one basic element of conversation. Anne’s views of frankness also echo with Emma's judgement of Jane Fairfax’s reserve in Emma. In Emma's words, Fairfax is "wrapt up in a cloak of politeness" and seems “determined to hazard nothing” (Austen, 2008, p. 132). Mr. Knightley also admits Fairfax’s want of "open temper” which "a man would wish for in a wife" (Austen, 2008, p. 225). John Mee focuses on the word "hazard" and even uses it as a part of the title "Jane Austen and the Hazard of Conversation" to describe Austen's conversable world in his work Conversable Worlds: Literature, Contention and Community 1762 to 1830. He explains that the word "hazard" echoes around the novels, especially Emma, usually in the context of judgments about when reserve ought to be put aside, particularly by women, but so too does a prior sense of relish at the free flow of conversation (Mee, 2011, p. 202). It implies that "proper conversation requires some risking of the self, some 'hazard' of engagement with the other” (Mee, 2011, p. 202). As for me, behind the word "hazard” is Austen’s wish of advocating sincerity because to hazard in conversation means to be frank and open when conversing with others. Thus sincerity as a basic element of proper conversation can be found in Austen's novels, especially articulated by Emma, Anne and other characters.

\subsection{Politeness}

Nancy S. Struever considers Austen's novels as ‘theliterary fulfillment” of Hume's programme, though maybe not correct, still revealing that there are some similarity between Austen's novels and Hume's programme, which lies in the promotion of politeness as a crucial factor of proper conversation (Struever, 1986, p. 94). Just as the first part has shown the result of sacrificing too much sincerity in conversation, Austen also warns the readers of the importance of politeness in her writings. One specimen can be found in Sense and Sensibility (1811). In Chapter 9, Willoughby is accused of "sacrificing general politeness to the enjoyment of undivided attention" where his heart is engaged and "slighting too easily the forms of worldly propriety" by Elinor (Austen, 1994, p. 47). Elinor thinks that "sacrificing general politeness" is bound up with the loss of “propriety” (Austen, 1994, p. 47). In other words, conversation without civility is not conversation of propriety.

Let's review Willoughby's criticism about Mr. Brandon when Marianne, Elinor and him are conversing together. Willoughby deems Brandon as a man "whom everybody speaks well of, and nobody cares about; whom all are delighted to see, and nobody remembers to talk to" (Austen, 1994, p. 48). In this sentence, these words "everybody", "all" and "nobody" indicate the absolute tone as well as the low reliability. Even when Elinor refutes that these words are unjust, Willoughby still insists on his own opinion, prejudiced and stubborn. He repeats that Brandon has “everybody's good word and nobody's notice” and confesses his dislike towards him (Austen, 1994, p. 49). In this way, Willoughby sacrifices too much politeness to express his biased feelings completely, thus his conversation is bound to be improper. From this example, it is not difficult to find how Austen appreciates the importance of civility in a proper conversation. 
In the next part, this thesis intends to provide more positive examples of Austen's efforts in community shaping by displaying proper conversation.

\section{Austen's Efforts in Community Building through Proper Conversation}

John Mee is skeptical about conversation's role in forging any larger community in Austen's novels, holding that "values of easy circulation and frank exchange are continually put under pressure” (Mee, 2011, p. 201). Yin Qiping holds a different view from Mee and provides some proper conversations from Pride and Prejudice, but actually Austen's efforts in community building through conversation can be easily seen from all her six novels. Based on her novels, this part will give more examples of proper conversation and elaborate on their functions of community building.

It is difficult to maintain both civility and sincerity through conversation, especially with those who we dislike, but Austen has vividly displayed us how to deal with it through her literary words. Yin has discussed an example from Pride and Prejudice, where Mr. Collins boasts about his own marriage that Charlotte and he "have but one mind and one way of thinking" and they "seem to have been designed for each other" (Austen, 2003, p. 185). As Charlotte's intimate friend, Elizabeth is fully aware of its lack of truth, but "could safely say that it was a great happiness where that was the case, and with equal sincerity could add that she firmly believed and rejoiced in his domestic comforts" (Austen, 2003, p. 185). Yin highly praises Elizabeth's answer as a perfect combination of both civility and sincerity for her only admitting that case was "a great happiness" and congratulating him on "his domestic comforts". She does neither confide Charlotte's true thoughts, nor betray her own principle of keeping honesty. According to Yin, a successful exchange of ideas and feelings among those in conversation often depends on decorum in terms of their attitudes, tones and diction (Yin, 2016, pp. 40-41). In this case, Elizabeth's attitudes, tones and diction all reflect her efforts in uniting both politeness and truth, conveying a strong sense of propriety. Thus Elizabeth's words are beneficial to the relationship of the Collins and contribute to the community shaping between them and herself.

Likewise, inChapter 15 of Northanger Abbey (1818), there is a conversation between John Thorpe and Catherine:

“But I say, Miss Morland, I shall come and pay my respects at Fullerton before it is long, if not disagreeable.”

“Pray do. My father and my mother will be very glad to see you.” (Austen, 2015, p. 100)

From the above conversation, Mr. Thorpe expresses his wish to visit Catherine at Fullerton, revealing his affection towards her. But Catherine avoids expressing herself and only replies that her parents would welcome him. Then Thorpe asks Catherine about her own feelings and she also answers him in an indirect way: "there are very few people I am sorry to see. Company is always cheerful” (Austen, 2015, p. 100). In other words, she does not say if she is willing to see him again. So why does not Catherine answer Thorpe's questions directly? It is very likely that the true answer is against the decorum and may do harm to the community building. If she refused to see him again, she would be impolite and hurt him; if she welcomed him by herself, she would lose honesty. But the reply that "there are few people I am sorry to see" holds the truth as well as consoles the listener. Thus truth is well combined with politeness in this short sentence, which also embodies Austen's imagination of community building. 
Besides, Yin concludes that the most difficult part of conversation is the way of criticism (Yin, 2016, p. 50). He illustrates how properly Elizabeth criticizes Darcy for his asocial personality in Pride and Prejudice. Apart from the proper way of criticism, I think Austen also demonstrates us how to deal with the criticism appropriately in her novels. Among her six novels, Emma, "perhaps her most concentrated account of a conversable world", is most closely related to the theme of criticism (Mee, 2011, p. 201). In the beginning of that book, Austen tells the readers that "Mr. Knightley, in fact, was one of the few people who could see faults in Emma Woodhouse, and the only one who ever told her of them" (Austen, 2008, pp. 9-10). In fact, Knightley is not only sharp at criticizing others, but also good at coping with others' criticism properly. In Chapter 5, Mrs. Weston advises Knightley not to interfere in the friendship between Emma and Harriet and adds that "it has been so many years my province to give advice, that you cannot be surprised, Mr. Knightley, at this little remains of office” (Austen, 2008, p. 32). In this sentence, "province” means responsibility and Mrs. Weston explains that her motive of criticizing Mr. Knightley is out of her responsibility to offer him suggestions. Thus suggestion is more easily to be accepted and it is conducive to form community. In addition, Knightley immediately thanks for her good advice and asserts that "it shall have a better fate than her advice has often found; for it shall be attended to" (Austen, 2008, p. 32). His warm and positive reply undoubtedly eases her misgivings and in return contributes to the community shaping.

Therefore, it seems that John Mee has underestimated Austen's contributions to the build-up of community through conversation, declaring that "Austen's novels more generally do not provide an orchestration of conversation into a larger sense of community" (Mee, 2011, p. 237). For instance, within the conversation between couples, we can feel their strong wish for larger community. In Chapter 58 from Pride and Prejudice, Darcy and Elizabeth confide their mutual affections to each other and find "it was too painful a subject to each to be dwelt on farther” (Austen, 2003, p. 318). Instead, they prefer to discuss the relationship between Mr. Bingley and Jane, feeling content with their growing intimacy and happiness. In the last chapter, entering into their married life, Darcy and Elizabeth are "always on the most intimate terms” with the Gardiners (Austen, 2003, p. 334). Both of them are "sensible of the warmest gratitude" towards the Gardiners, who help them unite together (Austen, 2003, p. 334). It indicates that Austen's ideal marriage is not about the couples becoming isolated with others or the society, but being more connected with them, through which the community is bound to become larger.

Let's look into the latter part of Mansfield Park (1814). When Fanny returns to her hometown Portsmouth, she is aware of the "deficiencies at home" but still conscious of building up the sense of community through proper conversation (Austen, 2000, p. 317). Her sister Susan's friendliness inspires her imagination to rebuild community. Fanny discovers Susan's imperfections, especially her impropriety of conversation and behaviors, that "her manners was wrong, however, at times very wrong - her measures often ill-chosen and ill-timed, and her looks and language very often indefensible” (Austen, 2000, p. 318). But she is determined to help Susan improve herself. Fanny gives Susan some advice, which is very "sound" and given "mildly and considerately" (Austen, 2000, p. 319). In other words, Fanny teaches and guides Susan in a very proper way, through whose conversation sincerity and civility are united together. In this way, Susan becomes more like "mistress of property" and Fanny even brings Susan to Mansfield Park with her (Austen, 2000, p. 318). In Mansfield Park, Susan is successfully integrated into the community: "first as a comfort to Fanny, then as an auxiliary, and last as 
her substitute, she was established at Mansfield, with every appearance of equal permanency” (Austen, 2000, p. 380). It not only indicates that community building is greatly owning to the propriety, especially the property of conversation, but also shows us how a community becomes larger through proper conversation.

\section{Conclusion}

In a conclusion, Austen's six novels all have embodied her devotions to conversation and community building. Through literary language, she has fully demonstrated us how to shape community through proper conversation. Only the conversation that unites both sincerity and politeness is bound to help form peaceful and warm community.

\section{References}

Austen, J. (1994). Sense and sensibility. London: Penguin Popular Classics.

Austen, J. (2000). Mansfield park. London: Wordsworth Classic.

Austen, J. (2003). Pride and prejudice. New York: Bentam Classic.

Austen, J. (2008). Emma. Oxford: Oxford University Press.

Austen, J. (2013). Persuasion. London: Harper Press.

Austen, J. (2015). Northanger Abbey. Nanjing: Yilin Press.

Mee, J. (2011). Conversable worlds: Literature, contentions and community 1762 to 1830. Oxford: Oxford University Press.

Struever, N. (1986). The conversable world: Eighteenth-century transformations of the relation of rhetoric and truth. In B. Vickers and N. Struever (Eds.), Rhetoric and the pursuit of truth: Language change in the seventeenth and eighteenth centuries. Los Angeles: William Andrews Clark Memorial Library.

Yin, Q. P. (2016). Conversation and community building in English literature. British and American Literature Review, 1(2016), 2440-2455. 